\title{
新規開発住宅地の空間構成と周辺微気候環境の関係に関する定量的把握 東南アジア・蒸暑気候地域における環境配慮型住宅地デザイン手法に関する研究（その1） \\ QUANTITATIVE STUDY OF RELATIONSHIP BETWEEN URBAN STRUCTURE AND AMBIENT MICROCLIMATE IN NEW DEVELOPED HOUSING AREAS Environmental-friendly housing area design methods in Tropic Southeast Asia Part 1 \\ 斉藤 圭*, イスマイルサイッド**, モハマドヒシャムラシディ***, 篠崎道彦**** Kei SAITO, Ismail SAID, Mohd Hisyam RASIDI and Michihiko SHINOZAKI
}

\begin{abstract}
The main purpose of this study is to develop a spatial and environmental database by collecting and generating several related digital data and build up a tools for data management and analysis in combination with GIS and numerical simulation software. Based on this database, to investigate objective knowledge of relationship between urban structure and ambient microclimate in new housing area in tropical country. As a result, it became clear that usability of developed spatial database and analysis environmental for a process which contains data modeling, management and visualization through the qualitative and quantitative consideration of numerical simulation effectively, and several new fundamental findings of relationship between deference of building type, open space, and block density and ambient physical environment objectively.
\end{abstract}

Keywords: New Housing Area, Building Type, Block Density, Ambient Microclimate, Malaysia 新規開発住宅地，住棟形式，街区密度，周辺微気候，マレーシア

\section{1 研究の背景と目的}

地球温暖化など，世界規模での環境問題が深刻化している昨今，問 題の防止・改善策のひとつとして様々な分野における $\mathrm{CO}_{2}$ の削減が急 務であると考えられており，具体的なスキームに即した対策案が実行 に移されつつある。建設分野においても再生可能な自然エネルギーの 積極利用が必要不可欠であるとされている。また，英国の BREEAM や日本の CASBEE など, 単体建築物のみならず, 地区・地域レベル において定量的に環境性能を評価しラベリングを行う仕組みが開発・ 運用されてきており，まちづくりや都市デザインの分野でも地域環 境に配慮した計画がますます重要になってきている。

ここで，近年急速に発展成長を続ける東南アジア諸国のひとつで あるマレーシアの建築・都市デザインに目を向けると，例えば新規開 発の都市型住宅地における建築物形状・配置や道路レイアウトとの 関係性をみるとその多くは高温多湿の蒸暑気候を考慮したデザイン とはなっていない。昨今, 自然共生型デザイン手法の研究・実践は, 特に欧米諸国を中心に活発に行われているが，その中で蓄積された 知識や手法を, 気候・風土・文化の異なる地域や都市にそのまま適 用することは難しい。これに加え，建築・都市デザインに物的な環 境条件を的確に反映させるためには，その対象とする地区や周辺の 地理・気候に関する環境情報の分析が必要不可欠となるが，マレー
シアにおいては, 空間情報インフラの整備・共有が発展途上であり, 特に複数街区レベルといったマイクロスケールの市街地を対象とし, 情報技術を応用した外部環境の解析・把握等はほとんど進められて いない。

以上に述べた背景を踏まえ本研究では, 自然エネルギーの積極的 かつ有効的な利用を考慮した環境への負荷低減に資する住宅地デザ イン手法の提案に向けたアプローチとして, 先ず関連デー夕を収集・ 整理し, 空間・環境データベースを整備する。これと併せ, 住宅地 における形態的な特徵や周辺環境の定量的把握を行うための作業環 境を構築する。次にこれらをべースとし，マレーシアの新規開発住 宅地における住戸・街区周辺の物的環境の現状について, 住戸夕イ プやレイアウト, 街区密度等の空間構成要素の相違と周辺微気候の 関係を定量的に把握し，基礎的な知見を蓄積することを本研究の目 的と設定する。

\section{2 研究方法と手順}

本研究は，以下の方法と手順に従い進める。

1. 当該研究に関連する分野，及び，マレーシアにおける研究到達点 の把握を目的とし，先行研究のレビューを行う。

2. 地図情報・航空写真等の各種空間デー夕，及び，気象観測デー夕を
マレーシア工科大学建築都市環境学部 上級講師・博士 (工学)

** マレーシア工科大学建築都市環境学部 准教授・Ph.D. *** マレーシア工科大学建築都市環境学部 講師・博士 (学術)

****芝浦工業大学デザイン工学部 教授・工博
Senior Lecturer, Faculty of Built Environment, University Technology Malaysia, Dr. Eng.

Assoc. Prof., Faculty of Built Environment, University Technology Malaysia, Ph. D. Lecturer, Faculty of Built Environment, University Technology Malaysia, Ph. D. Prof., College of Engineering and Design, Shibaura Institute of Technology, Dr. Eng. 
含む環境デー夕に関する調査・収集を行い, 欠落情報の新規作成・ 追加及びフォーマットの統一作業等を介して GIS 上に空間デー夕 ベースを構築する。

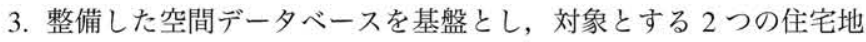
に関する棟数や密度等の定量的な基礎情報を算出し, 両者のフィ ジカルスタディを行う。これにより, 各住棟や街区の周辺微気候に 影響を及ぼしていると考えられる主要な空間構成要素を抽出する。

4. 住宅地における建物・街区周辺の微気候シミュレーションを行い, 数值結果の視覚化及び手順 3 で抽出した視点に基づいた定量的な 比較分析作業を通じ，その特徴を把握する。

5. 以上の結果を踏まえながら, 蒸暑気候下の新規開発住宅地におけ る建物及び街区の構成状況と周辺環境との関係性についての客観 的な特徴をまとめ, 環境配慮型の住宅地デザイン手法の提案に結 びつけるための基礎的・科学的知見を整理する。

\section{3 文献レビュー}

\section{1 都市デザイン分野での周辺微気候など物的環境との関連研究}

市街地レベルにおける自然共生型の環境デザイン手法に目を向け ると, 特にサスティナブルな都市開発・デザインの実践例として欧 米を中心に近年盛んに行われている11。しかし，気候情報の観測技 術・手法に関する知識や観測デー夕の蓄積を, 都市・景観デザイン の分野と結びつけて応用している研究事例については, 数はそれほ ど多くない2)。Gideon は都市のフィジカル面と熱的環境の関係につ いて, 気候区分に応じた 4 タイプ (Hot-humid, Cold-humid, Hot-dry, Cold-dry）の特徵に応じて主要な問題点や都市デザイン・気候要素に ついて私案を述べている ${ }^{3)}$ 。また近年では, 市街地レベルでの微気候 シミュレーション技術の発展と併せ, 建築物レイアウト・密度と風 通しに関する検討 ${ }^{4}$ や緑被率・屋上緑化のシナリオ等緑化と熱的環境 性能の関係を対象とした研究5) 6)など, 計測機器を用いた点的な実測 研究に対し, 建築物レイアウトや植生等のパラメータ変更と組み合 わせた面的なシミュレーション技術の応用例がみられる。

\section{2 マレーシアにおける自然共生型の都市・景観デザイン研究}

マレーシアにおける気候に関連する既往研究に着目すると, 都市・ 市街地レベルにおいて, Kubota, T. らは主要都市の住宅地内の風通 し7)や住宅内部の夜間換気の効果 ${ }^{8}$ について実測ベースの調査を行つ ている。また, Nugroho, A.M. らは一般的な住宅地における平屋のテ ラスハウスを対象に, その周辺の熱的快適性について CFDによるシ ミュレーションと実測結果の比較を行い，1階建てテラスハウスを主 とする住宅地内での通風の乏しさについて指摘している。またりー ラーチムニーによる建物室内の快適性向上に関する検討がなされて いる9)。また, Zainazlan. M.Z. らは年間気温, 相対湿度, 平均風速の 過去の気候デー夕を収集し, 建物室内における許容可能な熱的快適 性をパラメータとしたシナリオを設定し, 達成に必要な中立温度と 風速を算出し指標化を試みている ${ }^{10)}$ 。持続可能な開発の手法や建築 物形態の必要性を指摘しているが, 得られた算出値を具体の市街地 モデルに応用した検討はまだ成されていない。

\section{3 マレーシアにおける一般的な住宅について}

2009 年第 1 四半期時点において国内にストックされている住宅の うち約 40\%はテラス八ウス（内，2３階建て：約 52\%, 1 階建て： 約 48\%）で構成されており, マレーシアにおける住宅の主要夕イプ
となっている11)。テラスハウスはリンクハウスとも呼ばれ, 互いに 共有する壁面で繋がれた 3 棟かそれ以上の 1 連の建築物と定義され, 伝統的に格子状にレイアウトされた住宅地を形成する。Hassan, A.S. によると, テラスハウスは植民地時代に宗主国のイギリスによって 導入されたものであり, イギリスとは異なるマレーシアの南国特有 の気候への対応を目的とし, 強い日差しやスコールによる雨の浸入 を防ぐために庇を長くとった点や, 熱吸収を防ぐために壁面の材質 や色を変更した点など, 家屋に機能上の変更が加えられている。し かし, 当時の導入に掛かる主な目的は安価な建設コストと工期の短 さであり, また, グリッドタイプのレイアウトが主流であったこと も, 同様に工費削減を目的とし, 土地を可能な限り住棟の建設に割 り当てるためであった ${ }^{12)}$ 。

これら結果より, 以下の 2 点が明らかとなった。

1. マレーシアを含む熱帯蒸暑気候に属する国々においては, ヒート アイランド問題等に関連した都市・地域レベルでの広域な気候情 報の経年的収集や, 居室の熱的快適性など室内環境を対象とした 実測の研究事例は幾つかみられるものの, 外部環境における気温・ 湿度 ・ 風速など, 蒸暑気候下での重要指標を含む微気候と建築物 や道路・植栽等の物的環境との関連性を扱つた研究はまだ少ない。

2. テラスハウスを主として構成される新規開発の都市型住宅地は, デ ザインや計画手法が画一的であり, その導入背景や建物のボリュー ム・形状等に現地の気候など周辺環境は考慮されていない。

これらは蒸暑気候下の地域において, 複数街区を含むマイクロスケー ルの外部空間での自然環境と計画手法との関連性に着目した本研究 の必要性を示すものとして位置付ける。

\section{4 作業環境の構築と住宅地空間構成の把握 4.1 対象地域の設定}

本研究では, マレー半島南端のジョホール州の州都であるジョホー ルバル地域（図 1(a) 中の濃いグレー部分）に位置する2つの新規開 発型住宅地（図 1(b) 参照。以下, 住宅地 A と住宅地 B）に着目する。 当該住宅地 A（図 2(a)）, B（図 2(b)）は，それぞれ 90 年代前半と

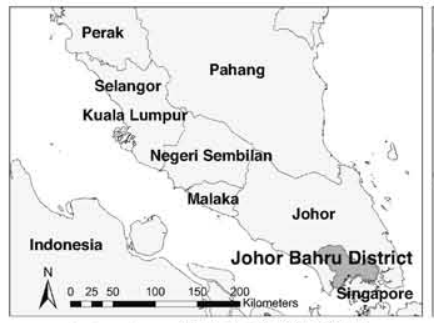

(a) マレー半島及び周辺諸国

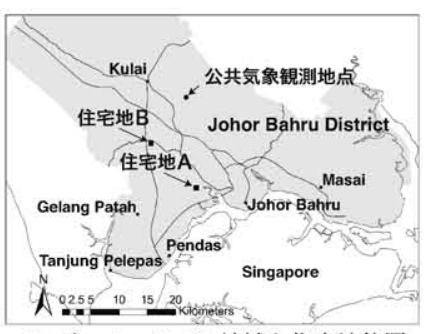

(b) ジョホールバル地域と住宅地位置
図 1 対象地域のロケーション

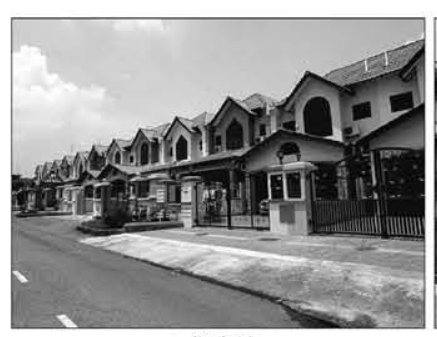

(a) 住宅地 A

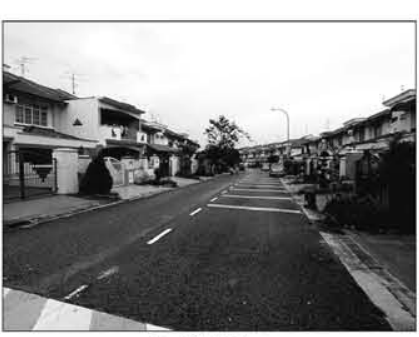

(b) 住宅地 B
図2 各住宅地内の様子 
2000 年代前半に作られた一般的な郊外型住宅地であり, 主として平 屋と 2 階建ての低層住宅で構成されている。

\section{2 データ収集・整備と作業環境構築}

ここでは先ず, 後の解析・図化作業に必要となる地図デー夕, 及び, 気象観測デー夕を収集・整備する。ベースとなる地図データは敷地 情報の管理用に公共機関によって整備されたベクターデータを入手 し, 建物・街区形状, 土地被覆デー夕等の入手困難なデジタルデー 夕については, 他のソース (紙地図・航空写真等) を用いてトレー スし作成した。樹木データはビデオカメラを用いた現地調査を通じ 形状・樹種を記録し, 航空写真と照らして位置を特定した。ここで は, 樹高が $10 \mathrm{~m}$ 前後のもののみを抽出し採用している。また, 気象 観測デー夕は，対象住宅地から最も近い公共気象観測地点（図 1(b) 中）の過去デー夕を入手した。表 1 はここでの整備済みデータの一 覧を示す。これらは空間データベースとして GIS 上に格納する。

表 1 整備済み空間データベースリスト

\begin{tabular}{|c|c|c|}
\hline カテゴリー & データタイプ & データ取得先 \\
\hline \multirow[t]{4}{*}{ 2Dベクター (ポリゴン ) } & 数地デー夕 & Department Survey and Mapping Malaysia \\
\hline & 街区デー夕 & オリジナル \\
\hline & 建物デー夕 & オリジナル \\
\hline & 土地被覆デー夕 & オリジナル \\
\hline \multirow{2}{*}{ 2Dベクター (ライン ) } & 道路 & Department Survey and Mapping Malaysia \\
\hline & 河川 & Department Survey and Mapping Malaysia \\
\hline 2Dベクター (ポイント ) & 樹木 & オリジナル \\
\hline 画像デー夕 & 航空写真 & Digital Globe (Google Earth) \\
\hline 紙面ベース地戝 & 樹木配漼計画図 & 地区役所・景䚁管理セクション \\
\hline
\end{tabular}

また本研究内では, GIS ソフトウェアをコアとし, 微気候シミュ レーションを担うソフトウェア $\left(\mathrm{ENVI}-\mathrm{met}^{\mathrm{i} \text { i1) }}{ }^{\mathrm{I}}\right)$ とを組み合わせデー 夕の管理・解析・図化を行うための作業環境を構築した。

\section{3 住宅地基礎情報の算出}

次に前節で整備した空間データベース及び GIS 環境を用いて, 対 象とする 2 住宅地の基礎的な情報の算出とその空間構成の特徵等に ついて述べる。図 3,4 はそれぞれ住宅地の中央付近から $850 \mathrm{~m}$ 四方を 切り出したものである。図中の各建物上の中央数字は建物高さ $(\mathrm{m})$ を, グレーの網掛けは建物タイプの相違, 街区上の丸囲み数值は街 区容積率 (\%) をそれぞれ示している。両図中の点線で囲われた部 分とモデル名については次章で説明を加える。また表 2 は, 各住宅 地の空間構成要素に関する基礎情報として, 建物・街区, 土地利用, 地区密度に着目しその算出結果を示している。

\section{4 住宅地の空間構成の特徵把握}

ここでは，前節までに構築した作業環境を用いて作成した空間的・ 定量的な情報を基に，両住宅地の空間構成に関する特徵についての 比較を行う。ここで抽出する特徴は, 建物及び街区の周辺環境に及 ぼす影響が大きいことが考えられ，これらは次章の住宅地内におけ る微気候シミュレーションを通じた分析時の着目点として設定する。

\subsection{1 地域内の建物状況について}

- 定性的にみた場合の特徵として建物分布に着目すると, 住宅地 $\mathrm{A}$ （図 3）は全体にグリッド状の街区配置となっておりそれに沿うよ うに建物が配置されている。テラスハウスは, 戸建て住宅の周辺 部に配されており，特に最も外側となる部分では南北に長手方向 持つテラスハウスが周りを囲うようにレイアウトされている。一 方住宅地 B（図 4）では, クラスター毎に空地を囲うように配され ており, 全体的にグリッド状のレイアウトとは異なる。
- 定量的にみた場合の特徵として表 2 中の両者の数值の差が大きい 建物棟数に着目すると, 同サイズの対象敷地内において, 住宅地 A は住宅地 B の約 2.6 倍となっている。このうち建物夕イプ別割 合に着目すると，住宅地 A は，户建て住宅が全体の $72 \%$, テラス ハウスは $28 \%$ となている。一方住宅地 B では, それぞれ $14 \%$, 78\%となっており, 両住宅地の建物夕イプにみる構成比は大きく異 なっている。

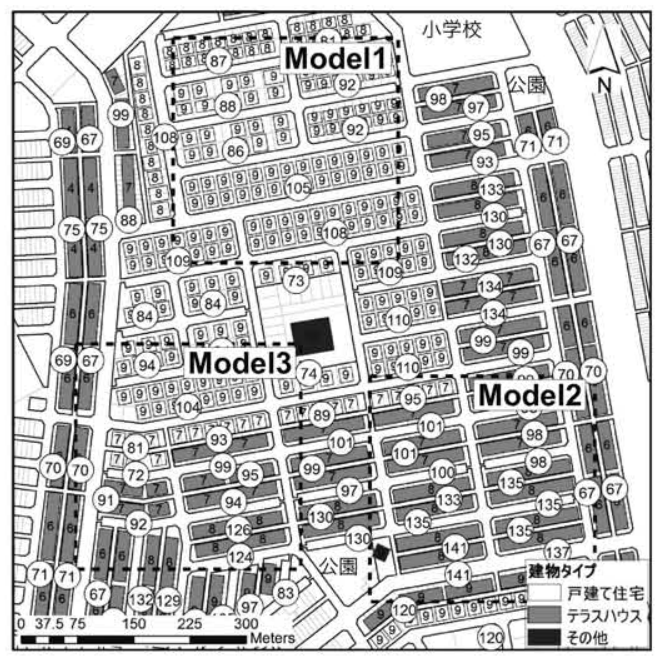

図 3 建物高さ・建物夕イプ・街区容積率 (住宅地 A)

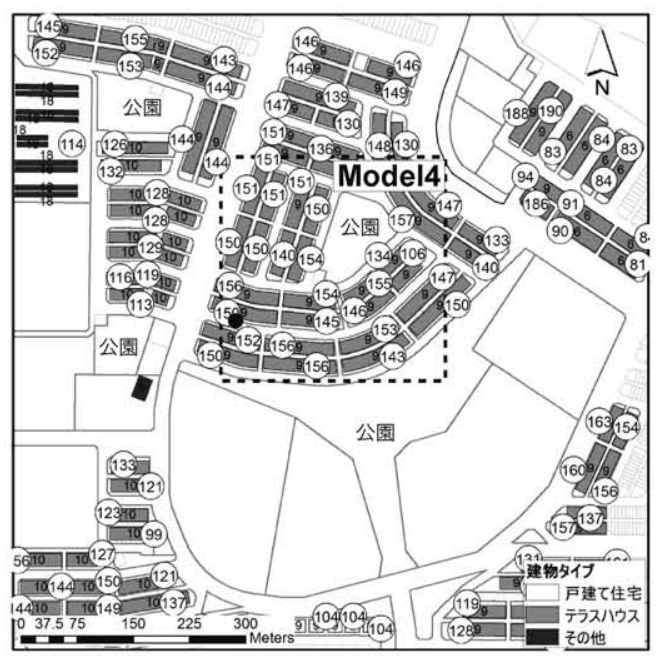

図 4 建物高さ・建物タイプ・街区容積率（住宅地 B）

表 2 両住宅地の建物・街区基礎データ

\begin{tabular}{|c|c|c|}
\hline 建物・街区基礎データ & 住宅地A & 住宅地B \\
\hline 平均建築面積 (m') & 606 & 953 \\
\hline 平均街区面積 $\left(\mathrm{m}^{2}\right)$ & 2,842 & 2,077 \\
\hline 合計建築面積 $\left(\mathrm{m}^{\prime}\right)$ & 216,357 & 127,798 \\
\hline 合計延べ休面積 $\left(\mathrm{m}^{2}\right)$ & 358,723 & 253,578 \\
\hline 建物梀数（棟） & 357 & 134 \\
\hline 建物タイプ別棟数（棟） & 戸(255), テ(100), 他(2) & 戸(19), テ(104), 他(11) \\
\hline 建物タイプ別割合（\%) & 戸(72), テ(28), 他(0) & 戸(14), テ(78), 他(8) \\
\hline $\begin{array}{r}\text { ※二戸一 } \\
\text { 土地利用データ (対象工 }\end{array}$ & 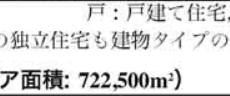 & $\begin{array}{l}\text { : テラスハウス, 他 : その他 } \\
\text { i上戸建て住宅に含めている }\end{array}$ \\
\hline オープンスペース率（\%) & 3.0 & 35.9 \\
\hline 道路率（\%) & 35.2 & 35.4 \\
\hline 宅地率 (\%) & 61.8 & 28.7 \\
\hline \multicolumn{3}{|l|}{ 密度データ } \\
\hline 地区建ぺい率 $(\%$, Net $)$ & 58.7 & 66.8 \\
\hline 地区容積率 (\%,Net) & 97.3 & 132.5 \\
\hline
\end{tabular}


これらより，一般的な住宅地の主要な建物夕イプである户建て住宅， 及び，テラスハウスの構成比の相違が空間的な特徵を示す重要な要 素のひとつであると考えられる。また，異なる建物夕イプ間のレイ アウトについて, 特にテラスハウスは連続壁面を持つ形態的な特徵 から，周辺環境に及ぼす影響が大きいことが考えられる。

\subsection{2 地域内の土地利用状況について}

- 定性的にみた場合の特徵として土地利用分布について特に両住宅 地間の差が大きい空地分布に着目すると，住宅地 A（図 3）では, 対象地の北側と南側に約 200 300 $\mathrm{m}^{2}$ の小規模な街区公園が配され ている。一方住宅地 B (図 4) では, 棟数にして約 20 30 の建物 で構成される各クラス夕ーの中央に $300 \sim 400 \mathrm{~m}^{2}$ 程度の街区公園が あり，図中南側には大規模な地区公園が配されている。

- 定量的にみた場合の特徵として表 2 中の両者の数值の差が大きい オープンスペース率に着目すると, 住宅地 A で $3 \%$ なっている。 一方住宅地 B では約 $36 \%$, 両者に面積にして約 12 倍の差がある ことがわかる。これに伴い宅地率の差も住宅地 A が住宅地 $\mathrm{B}$ の約 2 倍となっている。道路率は両住宅地間で同程度の約 $35 \%$ ある。 これらより, 本研究内で扱う住宅地の土地利用状況については, 両 対象地で占める割合が大きく異なるオープンスペース率が空間構成 上の特徵を示す重要な要素のひとつであると考えられる。また, 次 小節 4.4 .3 で詳細を述べるが両住宅地とも地区建ぺい率が比較的高い ことから，地域内のオープンスペースが周辺環境に及ぼす影響は大 きいことが考えられる。

\subsection{3 地域内の密度状況について}

- 定性的にみた場合の特徵として各住宅地の密度分布に着目すると, 住宅地 A（図 3）の街区容積率は, 中央北側の户建て住宅街区（約 $85 \sim 100 \%$ ), 中央南側のテラスハウス（約 90 140\%）, 周辺部の テラスハウス（約 70\%）となっている。一方，建物夕イプの約 8 割をテラス八ウスが占める住宅地 B（図 4）では, 建物高さに応じ てばらつきがあるものの，約 130 150\%の值を示している。

- 定量的にみた場合の特徵として表 2 中の両者の数值の差が大きい 地区容積率に着目すると，住宅地 A と B で，それぞれ約 97\%，約 132\%となっており約 35\%住宅地 B が A を上回っている。地区建 ぺい率については住宅地 A と B で同程度を示しており, それぞれ 約 59\%, 約 67\%を示している。

これらょり, 両住宅地における密度面からみた空間構成の特徵とし て, 地区建ぺい率は両住宅地間の差は小さいものの, 一般的な住宅 地としては両者とも比較的高い值を示しており街区内の空地は小さ いことがわかる。地区容積率は小節 4.4.1 と同様に, 建物夕イプの相 違によって街区内の容積率が異なることがわかり,この相違は住宅 地内の空間的な特徴を示す要素のひとつであると考えられる。

以上の両住宅地における空間的・定量的な情報の比較を通じ, 空 間構成要素として着目した建物・街区, 土地利用, 地区密度について それぞれ, 建物タイプ・形状, オープンスペース率, 地区容積率の相 違が住宅地内の物的環境を形成する特徵的な差異として抽出した。

\section{5 建物・街区周辺の微気候環境の把握}

ここでは, 前章で述べた 2 つ住宅地内において周辺環境に与え る影響が大きいと考えられる 3 つの空間構成要素と, 建物及び街区 周辺の微気候環境の関係性について, 数值シミュレーションを用い
てその特徵を定量的・客観的に明らかにする。

先ず，前章で空間構成上の重要な特徴のひとつであるとした建物 タイプ・形状について, その分類に基づいて住宅地 $\mathrm{A}$ と B から以下 の 4 ゾーン（各 $300 \mathrm{~m}$ 四方）を抽出する。

- Model1 : 户建て住宅街区 (図 3 中)

- Model2 : テラス八ウス街区 (図 3 中)

- Model3 : 戸建て十テラス八ウス街区 (図 3 中)

- Model4 : テラス八ウス街区十オープンスペース（図 4 中)

\section{1 微気候シミュレーションについて}

小節 4.2 で述べた微気候シミュレーションモデルを用い，上述し た Model1 4 を対象とした建物及び街区周辺の微気候環境の把握を 行う。この際, 屋外空間における保健性・快適性と結びつく基本指標 のひとつである気温と風速の 2 指標に着目する。シミュレーション 実行時に与える主要パラメー夕の初期設定注 2 ( は表 3 の通りである。 土地被覆注 3 にについては表 4 に示す通り, 土袞・コンクリート・アス ファルトの 3 種のいずれかに分類し, その上に建物注4), 芝, 及び, 樹木デー夕注5) を配置している。なお，人工排熱については計算モデ ルに含まれていないため本研究では考慮していない。

表 3 主要入力パラメー夕

\begin{tabular}{|c|c|}
\hline 位置 & 北繰 1.50 度, 東経 103.65 度 \\
\hline 計算日時・天候 & 3 月 21 日（晴天日） \\
\hline 計算時間 & $6 \mathrm{am} \sim 6 \mathrm{pm}$ \\
\hline 風速·風向 & $1.6(\mathrm{~m} / \mathrm{s})$ 高さ $10 \mathrm{~m}$ 地点, $40^{\circ}$ (北東方向から) \\
\hline 境界·初期条件 & 気温 $298.5(\mathrm{~K})$, 相対湿度 87.9(\%) \\
\hline グリッドサイズ & $\begin{array}{c}400 \mathrm{~m} \times 400 \mathrm{~m} \times 50 \mathrm{~m}, \Delta \mathrm{x}=\Delta \mathrm{y}=\Delta \mathrm{z}=2.5 \mathrm{~m} \\
(\text { 高さ方向 } 2.5 \mathrm{~m} \text { まで } \Delta \mathrm{z}=0.5 \mathrm{~m} \text { ) }\end{array}$ \\
\hline
\end{tabular}

\begin{tabular}{ccccc}
\multicolumn{2}{c}{ 表 4} & \multicolumn{2}{c}{ モデル別土地被覆の割合 } & \\
土地被覆 & Model1 & Model2 & Model3 & Model4 \\
\hline 士.裹 & $22.2 \%$ & $14.3 \%$ & $19.6 \%$ & $18.2 \%$ \\
コンクリート & $56.9 \%$ & $53.2 \%$ & $49.2 \%$ & $47.8 \%$ \\
アスファルト & $20.9 \%$ & $32.5 \%$ & $31.2 \%$ & $34.0 \%$ \\
\hline
\end{tabular}

ここで図 5 は, 上述した条件・パラメー夕の設定で建物及び植生 等をレイアウトした住宅地 $\mathrm{B}$ 内の中央付近（図 4 中の黒丸地点）に おける 3 月 21 日午前 0 時から 24 時間のシミュレーションを行った 気温の結果と, 同日の公共気象観測地点における時刻別観測值注6)の 気温変化を示している。結果から ENVI-met モデルによる計算值は, 日の入りから日の出までが平均で約 $1.2^{\circ} \mathrm{C}$, 日の出から日の入りまで が平均で約 $2^{\circ} \mathrm{C}$ 観測值よりも低く算出されることが分かった。この 傾向は, 類似の熱帯気候下の市街地で同モデルを利用した既往研究 ${ }^{13)}$ 内での実測值と計算值の比較においても同様の結果が示されている。 これは ENVI-met モデル内では人工排熱による影響が考慮されてい ないことが原因のひとつとして考えられる。

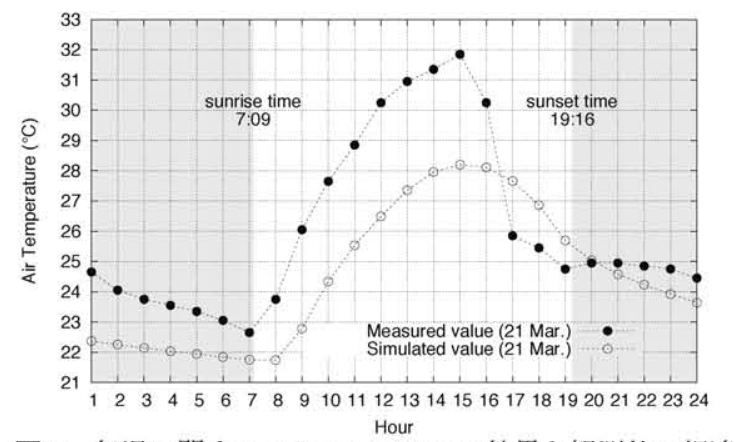

図 5 気温に関するシミュレーション結果と観測値の相違 


\section{2 建物・街区周辺の微気候シミュレーション}

図 8 11 は, 建物夕イプ別で 4 分類した各ゾーンにおける (a) 街区 形状及び番号・樹木位置, 建物・街区周辺の 14 時時点の (b) 気温と (c) 風速の分布を示している。図 (b) と (c) 中の建物上の数字は建物 高さ $(\mathrm{m})$ を表す。本節では, 各指標値の結果と建物タイプとの関係 について，先ず図中の分布形状をもとに定性的な特徵を把握する。

\subsection{1建物タイプと周辺気温の関係}

- 戸建て住宅に着目すると, 図 8(b) 中 A 部分に示す, 隣棟間隔が 10 20m 程度と広く, 各户の敷地内にまとまった庭をもつ戸建て 住宅の周辺において, 局所的に他よりも色の濃い分布が見られる。 これは同図中 B 部分や, 図 10(b) 中 A 部分に示す户建て住宅周辺 部においても同様の特徵が見られる。

・テラスハウスに着目すると, 図 9(b) に示す長手方向が約 $100 \mathrm{~m}$ の 住宅周辺では, 街区内部または道路上にかかわらず, 他のモデル と比較して全体に高い値の分布が広がつている。図 10(b) 南側の長 手方向が約 50m の同タイプの住宅周辺では, 同図 9(b) と比較して やや值の低い分布が広がっている。図 11(b)では，住宅の周辺で全 体的に低い值の分布が見られる。特に, 同図中 A 部分に示す周辺 を囲まれるように配された住宅周辺で低い值を示している。

・オープンスペースに着目すると, 図 10(b) 中 B 及び図 11(b) 中 B に示すオープンスペース内部では他と比較して低い值が広がって おり, 各モデル内で最も低い值が現れている。しかし, どちらの モデルも周縁の道路面上では，気温の低下は見られない。

これらょり, 各指標値の分布形状からみた場合, 隣棟間隔の広いま とまった空地部分をもつ戸建て住宅部分で他よりも気温が低くなっ ていること, また特に Model2 のテラスハウス周辺では, 建物長手方 向のサイズ及びレイアウトの相違が気温変化に影響を与えているこ とが分かった。また表 4 から同 Model2 の人工被覆割合が他のモデ ルと比較して高いことも周辺気温の上昇に影響している可能性があ る。オープンスペース部分では緑被や樹木の影響から他よりも低い 気温となる。このことは本研究の対象地域と同じ気候下であるシン ガポールにおける既往研究 (例えば Chen, Y. ${ }^{14}$ ) , Wong, N.H. ${ }^{15)}$ ) で緑 地のもつ微気候緩和効果について実測及び計算によって指摘されて おり, 本研究でも同様の結果が確認された。その範囲はオープンス ペースの内部に限定されており, 周辺の住宅部分まで影響が及んで いないことが分かった。

\subsection{2 建物タイプと周辺風速の関係}

- 戸建て住宅に着目すると, 図 8(c) 中の A 部分に示す隣棟間隔約 $3.5 \mathrm{~m}$ の住宅周辺では風速は非常に低く, これは同タイプの住宅を 含む他の街区内においても同様の傾向がみられる。同図中 B に示 す敷地内にまとまった庭を持つ住宅の周辺や，同図中 C 部分の道 路上, 特に交差点付近においては, A 部分と比較して $1 \mathrm{~m} / \mathrm{s}$ 程度高 い值の風速がみられる。

・テラスハウスに着目すると, 図 9(c), 10(c) 中の直線道路上で他よ りも高い值の分布が見られる。同図中の建物間の背割り道路部分 （隣棟間隔約 $7.8 \mathrm{~m} ）$ では風速が非常に低くなっている。また, 図 11(c) 中の道路上では, 平行的に建物が配されている図 9(c) に示す 約 $0.8 \sim 1.0 \mathrm{~m} / \mathrm{s}$ と比べ, 同じ建物夕イプにもかかわらず約 $0.2 \sim 0.4 \mathrm{~m} / \mathrm{s}$ と低い值の分布となっている。

・オープンスペースに着目すると, 図11(c) の中央オープンスペース
内部では比較的高い值の分布が広がっており, 同オープンスペー スと接続する南側道路上でも周辺よりも值が高くなっている。 これらより, 同じ建物タイプにおいても, 建物形状やレイアウトの 相違が周辺の風速に影響を与えていることについて, その程度や範 囲が分布形状から明らかとなった。また, 地区内のオープンスペー スによってその周辺部分へ風通し等の影響が及ぶことが分かった。

以上までに述べた個別の建物周辺や街区周辺の状況については, 次 節で定量的にその特徵を述べる。

\section{3 建物タイプ・形状及び街区密度と周辺環境の関係}

続いて, 建物及び街区の周辺環境を個別に把握することを目的と し, 各建物及び各街区の周辺に図 7 に網掛けで示す領域 (バッファ

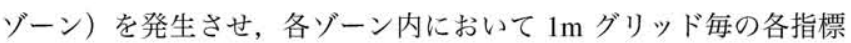
値を合計し平均をとる。ここで，両対象地における平均隣棟間隔は 約 $5.7 \mathrm{~m}$, 各街区境界線から隣接する道路の中心線までの平均距離は 約 $5.0 \mathrm{~m}$ であり, これらは居住者や地域住民の生活・歩行空間である ことからバッファ距離を $5 \mathrm{~m}$ と設定した。また, 本研究内で扱う建物 は全て 2 階建て以下であり, 高さの差が小さい。これらょり, 同距 離バッファ内の計測結果を比較することは, 周辺環境を個別に捉え る手段として有効であると考えた。図 12 は建物縦横比（各建物の長 手方向長さを短手方向長さで除したもの）に着目した場合の建物周 辺における各指標の平均值を, 図 13 は街区容積率に着目した場合の 街区周辺における各指標の平均值をプロットしたものを示す。

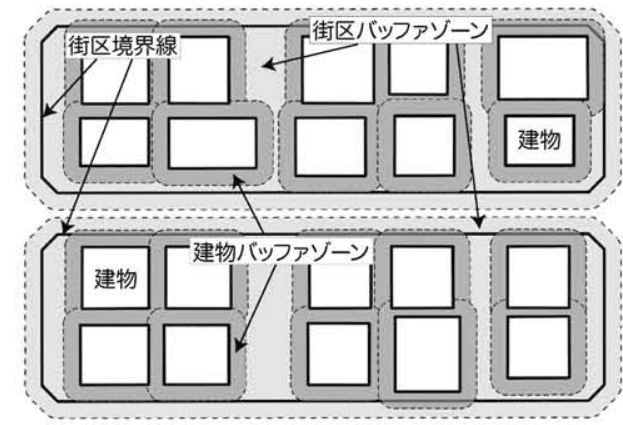

図 7 建物・街区周辺の集計用バッファゾーン概念

\subsection{1建物タイプ・形状と各建物周辺環境について}

ここでは先ず, 建物夕イプ及び各建物の縦横比の相違と, 各建物周 辺の平均気温及び平均風速との関係について定量的に特徵を捉える。

\section{建物縦横比と周辺平均気温}

- 図 12(a) に示す通り, 建物周辺では建物夕イプ・形状にかかわらず 平均気温の差が全体で約 $1.8^{\circ} \mathrm{C}$ に収まっている。

- 図 12(a) 中 A 部分に示す建物縦横比が 1 に近い户建て住宅の周辺 では，その差が約 $1 \sim 1.5^{\circ} \mathrm{C}$ の間に分散している。

- 同図中 B 部分に示す, 縦横比が 3 4 のテラスハウス周辺では, Model2 $>$ Model3 $>$ Model4 の順に周辺平均気温が高く, Model2 と Model4 では約 1 1.5 ${ }^{\circ} \mathrm{C}$ の差が生じている。

これらょり，4つのモデル内を全体的にみた場合, 建物周辺の平均気 温差は $2^{\circ} \mathrm{C}$ 未満に収まることが分かった。建物タイプ別に細かくみ た場合, 戸建て住宅周辺では小節 5.2.1 で述べた他より大きく取られ た隣棟間隔やまとまった庭の有無により, 平均で $1 \sim 1.5^{\circ} \mathrm{C}$ 気温差が 生じていることが分かった。またテラスハウス周辺では, 同縦横比を 持つ建物で比較すると, レイアウト及び周辺環境の相違により平均 

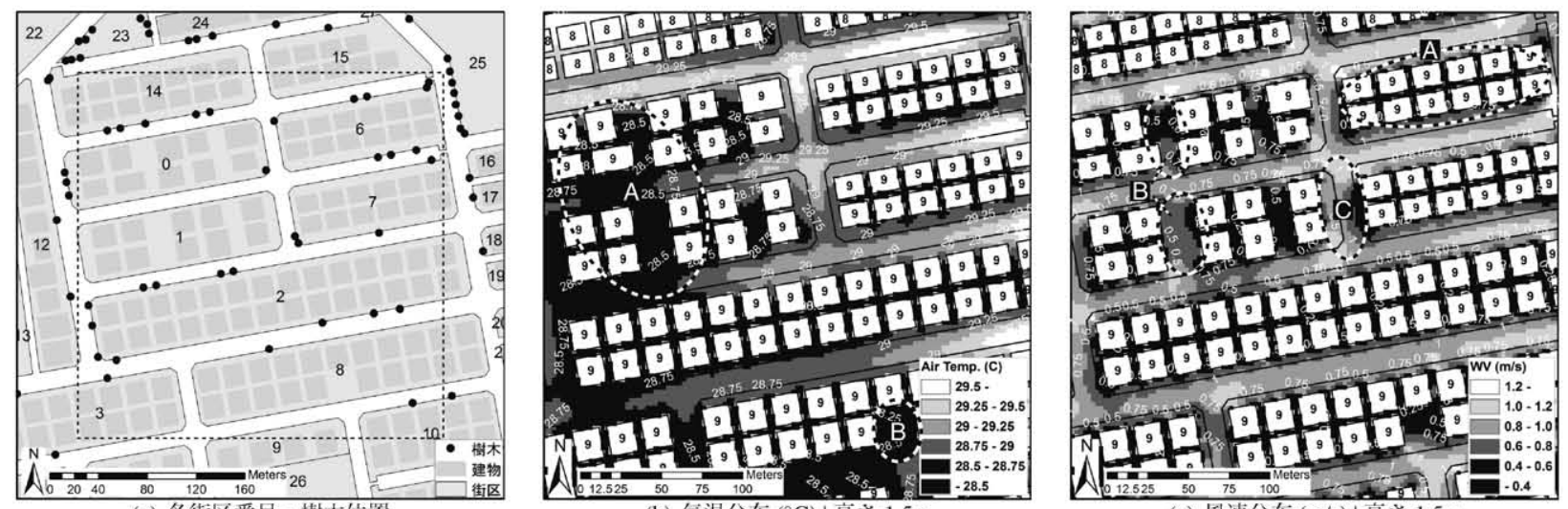

図 8 住宅地内の街区・樹木情報及び気温・風速の分布（Model1）
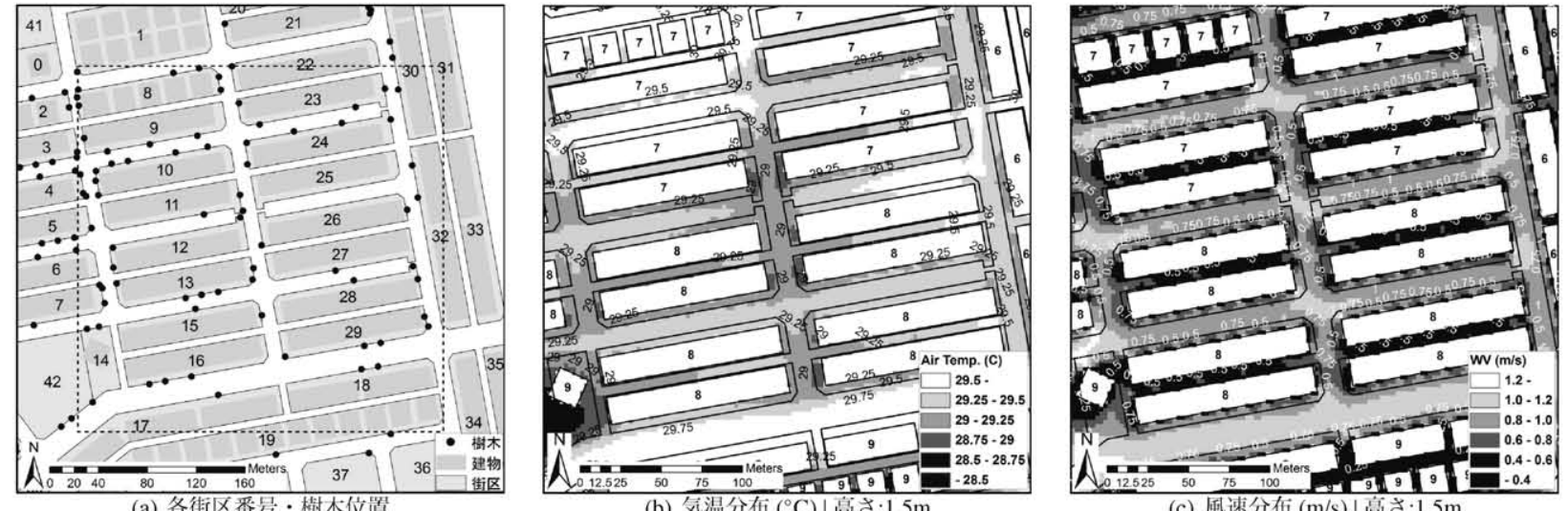

図 9 住宅地内の街区・樹木情報及び気温・風速の分布（Model2）
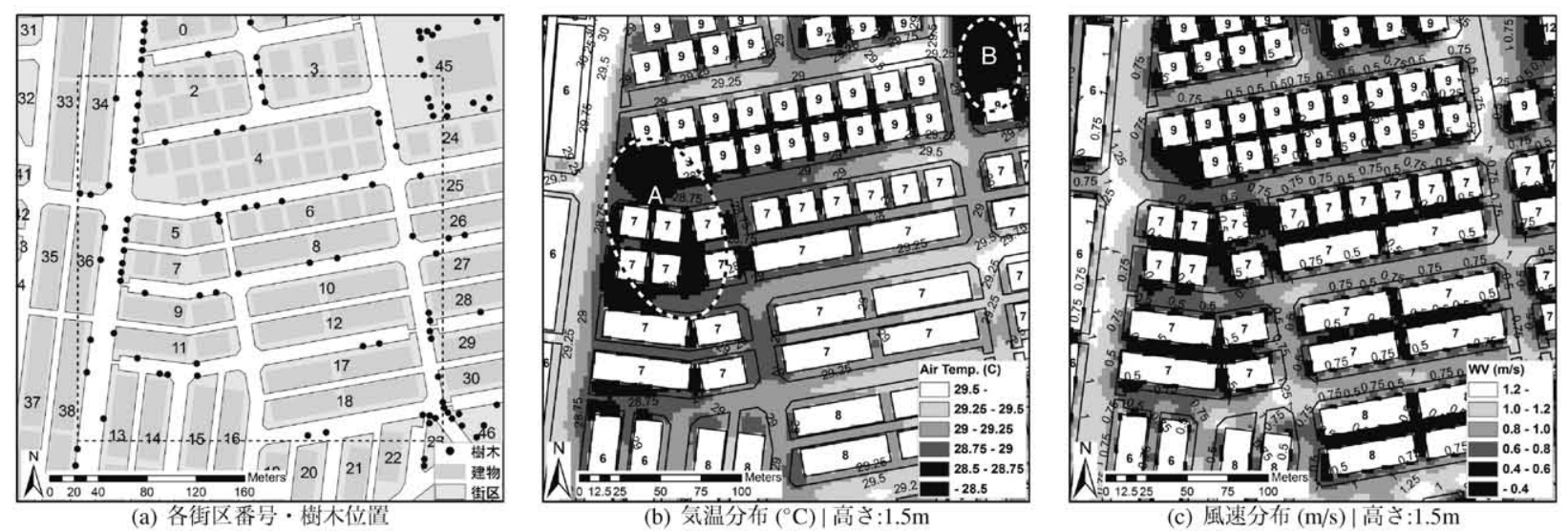

図 10 住宅地内の街区・樹木情報及び気温・風速の分布（Model3）
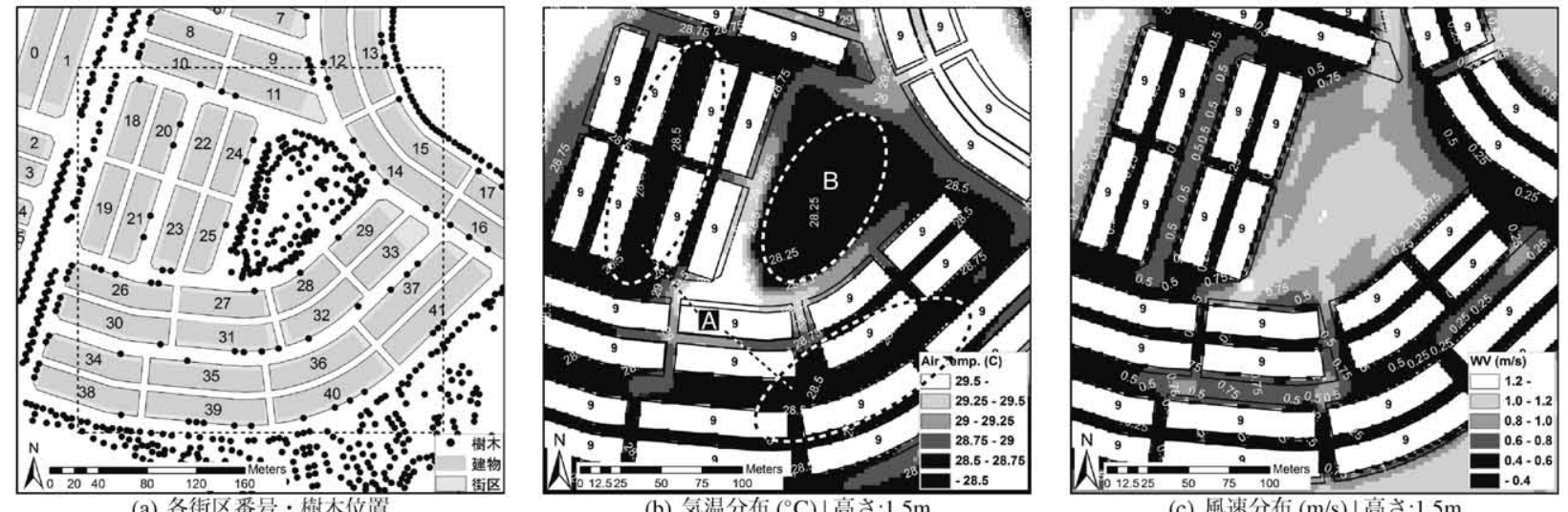

図 11 住宅地内の街区・樹木情報及び気温・風速の分布（Model4） 
約 1 1.5 $5^{\circ} \mathrm{C}$ (Model2 >Model4）の差が生じていることが分かった。

\section{建物縦横比と周辺平均風速}

- 図 12(b) に示す通り, 建物周辺では建物の縦横比にかかわらず平均 風速が $1.0 \mathrm{~m} / \mathrm{s}$ 以内に収まっている。

- 同図中 A 部分に示す, 縦横比が 3 4 のテラスハウス周辺では, Model3>Model2>Model4 の順に平均風速が高い。最も低い Model 4 では全体の約 $66 \%$ の建物周辺で $0.4 \mathrm{~m} / \mathrm{s}$ 以下となっている。

- 同図中 $\mathrm{B}$ 部分に示す, 平均風速が $0.6 \mathrm{~m} / \mathrm{s}$ 以上となる建物に着目 すると, Model1 及び Model3 の一部の户建て住宅と, Model2 と Model3 のテラスハウスのほとんどが含まれている。

これらより，4つのモデル内を全体的にみた場合, 建物周辺の平均風 速は約 $1 \mathrm{~m} / \mathrm{s}$ に収まることが分かった。建物夕イプ別に細かくみた場 合, 小節 5.2.2 で述べた分布形状の特徵と併せ, 建物周辺に空地を配 した一部の戸建て住宅と, 平行配置型のテラスハウスでは $0.6 \mathrm{~m} / \mathrm{s}$ 以 上の風速となる。しかし, Model4 の建物周辺の多くでは他より低い 值 $(0.4 \mathrm{~m} / \mathrm{s}$ 以下) であることが分かった。これは縦横比の大きい建 物が周辺を取り囲むように配したことによって内部の風通しが遮ら れていることが考えられる。

\subsection{2 街区密度と各街区周辺環境について}

次に, 各街区内の密度 (容積率) の相違と, 各街区内部及び周辺 の平均気温及び風速との関係について定量的に特徵を捉える。図 13 中の数字は図 8(a) 11(a) 中の各街区番号と対応する。

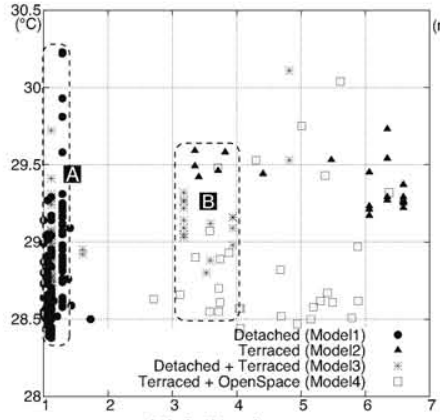

(a) 平均気温 | 高さ: $1.5 \mathrm{~m}$

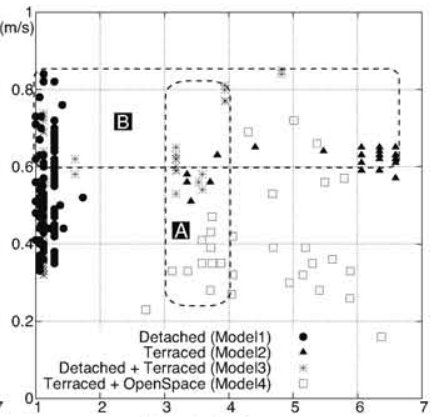

(b) 平均風速 | 高さ: $1.5 \mathrm{~m}$
図 12 各建物周辺における各指標の平均值と建物縦横比の関係

\section{街区容積率と周辺平均気温}

- 図 13(a) 中 A 部分に示す, 容積率約 80 100\%の街区内とその周辺 では, 建物夕イプの相違に依らず $28.5 \sim 30^{\circ} \mathrm{C}$ の間に分散している。

- 同図中 B 部分に示す, 容積率 $140 \%$ 付近では, 同夕イプのテラス 八ウスを含む街区が Model2>Model4 の順で含まれており，その相 違は約 $1^{\circ} \mathrm{C}$ となっている。

- 同図中 C 部分に示す, 平均気温 $29^{\circ} \mathrm{C}$ 未満となる街区に着目すると, Model1 及び Model3 の一部と, 分布図 11(b) 中 A でみた Model4 の，中心部を囲むように配した建物をもつ街区が含まれる。

これらより, 容積率が 80 100\%となる街区とその周辺に限定すると, 街区容積率を切り口にみた場合, 建物タイプ及びレイアウトの相違 が平均気温に与える影響は小さいことが分かった。また，容積率が 約 140\%前後の場合, 同程度の容積率で同じ建物タイプのテラス八ウ スであれば, 平行配置型（Model2）よりもオープンスペース囲み型 (Model4) の方が街区内及び周辺の平均気温で約 $1^{\circ} \mathrm{C}$ 低いことが分 かった。また, 戸建て住宅で構成される街区については, 各街区間
の容積率の差異は小さいものの, まとまった庭部分を配した住宅を 含む街区で低い值を示すことが分かった。

\section{街区容積率と周辺平均風速}

- 図 13(b) 中 A 部分に示す容積率約 80 100\%の街区内とその周辺で は, 平均気温と同様に容積率の相違に依らず, 平均 $0.6 \sim 0.9 \mathrm{~m} / \mathrm{s}$ の 間に分散している。

- 同図中 B に示す, 平均風速が $0.7 \mathrm{~m} / \mathrm{s}$ 以上を示す街区に着目すると, 容積率の相違にかかわらず，街区内にまとまった庭部分を持つ户 建て住宅を含む Model1 と, 平行配置型のテラスハウスの Model2 と Model3 の一部が含まれている。

- 全体的な傾向として, 同図中 C (楕円内部) に示す街区容積率が 100\%以下となる場合, ほぼ全ての街区内部とその周辺で平均風速 を $0.6 \mathrm{~m} / \mathrm{s}$ 以上となっている。

これらより, 容積率が約 80 100\%となる街区とその周辺に限定する と, 街区容積率を切り口にみた場合, 街区容積率の相違が平均風速に 与える影響は小さいことが分かった。小節 5.3.1 での各建物周辺での 風速の特徴と同様に, 街区内にまとまった庭部分をもつ Model1 の一 部と, 平行配置型テラスハウスの Model2 と Model3 の一部を含む街 区内部及び周辺で平均 $0.7 \mathrm{~m} / \mathrm{s}$ の風速となることが分かった。また街 区容積率で $100 \%$ 以上比較的密度の小さい街区では, 平均で $0.6 \mathrm{~m} / \mathrm{s}$ 以上の風速となることが分かった。

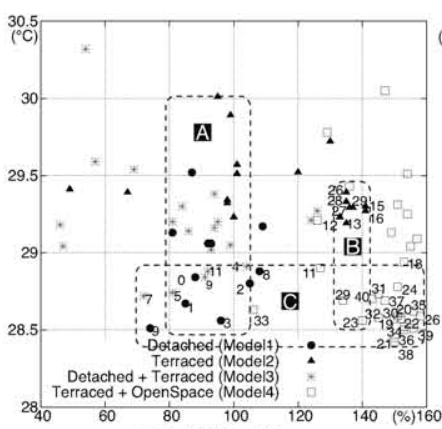

(a) 平均匃温 | 高さ: $1.5 \mathrm{~m}$

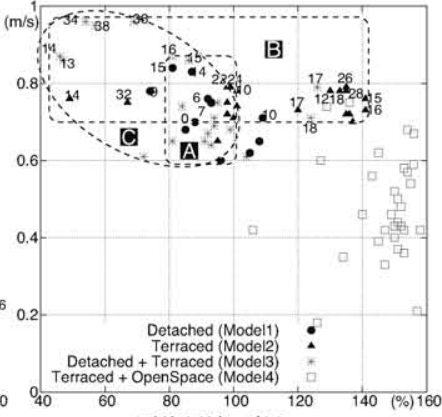

(b) 平均風速 $\mid$ 高さ: $1.5 \mathrm{~m}$
図 13 各街区周辺における各指標値の平均値と街区容積率の関係

\section{6 結語}

蒸暑気候のマレーシアで住宅地内の環境情報を客観的に評価・分 析を行うためのツールとして, 先ず地図データ及び気候デー夕を収 集・整備し, GIS を用いて空間データベースを作成した。これらと 微気候シミュレーションを組み合わせ, 住宅地の主要な空間構成要 素と建物・街区周辺における微気候環境との関係について考察を行つ た。定性的・定量的な比較を通じ，2つの対象地区内に設定した 4 モ デルを全体的な視点で見ると, 気温及び風速の変化は小さいことが 分かった。しかし各モデル内の建物タイプ・形状やレイアウト及び 街区密度等の物的な相違を細かく見た場合, 住宅地内の構成要素の 相違が周辺環境に与える影響が明らかとなった。これらを本研究の 知見として，4 章末で述べた 3 つの主な空間構成要素毎に整理する。 先ず建物タイプ・形状に着目すると以下の特徴が得られた。

・隣棟間隔が 10 20m と広く, 各戸の敷地内にまとまった庭を配す る戸建て住宅街区では, 他の户建て住宅街区と比較して建物周辺 の平均気温で約 $1 \sim 1.5^{\circ} \mathrm{C}$ 低い值となる。

・同じ縦横比のテラス八ウスをもつ街区では, レイアウトによって 
建物周辺の平均気温が異なり，オープンスペース囲み型と平行配 置型を比較すると前者が約 $1 \sim 1.5^{\circ} \mathrm{C}$ 低い值となる。

- 建物周辺の平均風速でみると, まとまつた庭を持つ戸建て住宅と 平行配置型のテラスハウスで他より高い約 $0.6 \mathrm{~m} / \mathrm{s}$ 以上となる一方, 周辺を囲うょうに配されたテラス八ウスの内側では通風が遮られ ていると考えられ，他街区より低い約 $0.4 \mathrm{~m} / \mathrm{s}$ 以下となる。

次に, 地区内のオープンスペースに着目すると以下の特徵が得られた。

・オープンスペース内部では周囲よりも低い気温分布となるが，オー プンスペース外側にまでは気温の低減に資する影響は見られず，効 果の範囲は限定的であると考えられる。

・オープンスペース内部では周囲よりも大きい風速が得られ，その 風は周辺の道路上まで影響を及ぼしており，地区内に通風をもた らす役割を担うことに繋がる可能性がある。

最後に街区容積率の相違に着目すると以下の特徵が得られた。

・ 容積率が約 80 100\%の範囲にある場合, 街区内部及び周辺の気温 の変化及び風速の変化に与える影響は小さい。

- 容積率が $140 \%$ 前後のテラス八ウス街区を比較した場合, オープン スペース囲み型のレイアウトの方が平行配置型と比較して街区内 部及び周辺の平均気温が約 $1{ }^{\circ} \mathrm{C}$ 低い值となる。

・容積率が 100\%以下の比較的密度の小さい街区では，街区内部及び 周辺の平均風速が約 $0.6 \mathrm{~m} / \mathrm{s}$ 以上と他の街区より高い值となる。

今後の展開として, 第 3 章で述べた通り現在マレーシア国内の主要 な建物夕イプであるテラス八ウスについて, 本研究を通じて得られ た知見をベースとし，そのレイアウト・形状のバリエーションが住 宅地内の周辺微気候に与える影響についてより検討を深める必要が あると考える。また，本研究内では主要な構成要素として扱わなかっ た緑被部分及び樹木による周辺気温の低減効果等についても平行し て検討を加える必要があると考える。

\section{謝辞}

本研究は, University Technology Malaysia 及び芝浦工業大学の研究 助成を受けて行った研究成果の一部です。記して感謝申し上げます。

\section{注}

注1) 独 Johannes-Gutenberg University の Dr. Michael Bruse らによって開発され ている 3 次元都市父候モデル及びシミュレータ。開発元であるヨーロッパ における研究事例に加え, 例えば東南アジアのシンガポールにおける緑化手 法の研究 14) 15) や日本国内における複数街区スケールでの建物形態と周辺微 気候の関係の検討16) など, 学術的用途で複数の利用実績がある。計算モデ ルの詳細は文献 $\left.{ }^{17)}{ }^{18}\right)$ 及び http://www.envi-met.com/を参照。同 URL からフ リーダウンロード可能。本研究内では Ver $3.1 \beta 4$ を使用。

注2) 月別父象観測デー夕 (Malaysian Meteorological Department, 2008) の值を利 用。全ての指標值が年間平均と最も近い值となる 3 月を選択した。また計 算・境界設定等の概要は以下の通りである ${ }^{18}$ 。

- 乱流モデル: 楣準 $\mathrm{k}-\varepsilon$ モデル

流入境界: 鉛直速度分布一定

流出境界: 法線方向の公配ゼロ

側面・上空境界: slip 壁

地表面 ·建物壁面境界: no-slip 条件

注3）土地被覆の設定条件については ENVI-metにあらかじめ登録されている Soil Database から最も対象地の現況に近いものを選択しその值を用いて計算し た。主なものは以下の通りである。

一 日射反射率: 土境 (0), コンクリート $(0.4)$, アスファルト $(0.2)$

長波放射率: 土壃 $(0.98)$, コンクリート $(0.9)$, アスファルト $(0.9)$

土裹表面及び内部の初期温度設定は 293(K), 相対湿度は地下 $0-0.2 \mathrm{~m}$ まで $50 \%, \quad 0.2-2 \mathrm{~m}$ が $60 \%$
注4) 建物の設定条件については，全ての建物共通で以下の通りである。 日射反射率: 壁面 (0.25), 屋根面 (0.3)

熱貫流摔: 壁面 (1.94), 层根面 (6)

注5) 樹木・草については夕イプ, 高さ $(\mathrm{m})$, 高さ方向に 10 分割したそれぞれの 地点における LAD (Leaf Area Density:葉密度)によって記述される。ここ では ENVI-met にあらかじぬ登録されている Plant Database から最も対象 地の現況に近いものを選択しその值を用いて計算した。しかしこれらは南国 特有の樹木形状・葉密度等の情報を反映していない。より正確なシミュレー ション結果を得るために，今後この点についての検討が必要である。本研究 内で使用したモデルの詳細は以下の通りである。

- 樹木モデル:

ータイプ (deciduous:落葉性)，高さ $(\mathrm{H}) 10 \mathrm{~m}$

- LAD 值 $(\mathrm{z} / \mathrm{H}=0.1,0.2, \ldots, 1.0, \mathrm{z}$ :地面からの高さ, $\mathrm{H}$ :樹木高さ)

$0.075,0.075,0.075,0.075,0.250,1.150,1.060,1.050,0.920,0.000\left(\mathrm{~m}^{2} / \mathrm{m}^{3}\right)$

- 草モデル:

-タイプ (grass:草), 高さ $(\mathrm{H}) 0.05 \mathrm{~m}$

- LAD 值 $(\mathrm{z} / \mathrm{H}=0.1,0.2, \ldots, 1.0, \mathrm{z}$ :地面からの高さ, $\mathrm{H}$ :草高さ)

$0.300,0.300,0.300,0.300,0.300,0.300,0.300,0.300,0.300,0.300\left(\mathrm{~m}^{2} / \mathrm{m}^{3}\right)$

注6) 時刻別気像钼測データ (Malaysian Meteorological Department, 2008)

\section{参考文献}

1) Ritchie, A. : Sustainable Urban Design, Taylor \& Francis, 2003

2) Emmanuel, R. : An Urban Approach to Climate-Sensitive Design -Strategies for the Tropics, Spon Press, 2005

3) Golany, G.S. : Urban Design Morphology and Thermal Performance, Atmospheric Environment 30(3), pp.455 465, 1996

4) $\mathrm{Ng}, \mathrm{E}$ : Policies and technical guidelines for urban planning of high-density cities - air ventilation assessment (AVA) of Hong Kong, Building and Environment 44, pp.1478 1488, 2009

5) Wong, N.H. and Jusf, S.K. : GIS-based greenery evaluation on campus master plan, Landscape and Urban Planning 84, pp.166 182, 2008

6) Fahmy, M., et al. : On the development of an urban passive thermal comfort system in Cairo, Egypt, Building and Environment 44(9), pp.1907 1916, 2009.9

7) Kubota, T. and Ahmad, S. : Wind Environment Evaluation of Neighborhood Areas in Major Towns of Malaysia, J. of Asian Architecture and Building, 5(1), pp.199 206, 2006.5

8) Kubota, T., et al. : The effects of night ventilation technique on indoor thermal environment for residential buildings in hot-humid climate of Malaysia, Energy and Buildings 41(8), pp.829 839, 2009.8

9) Nugroho, A. M., et al. : A Preliminary Study of Thermal Comfort in Malaysia's Single Storey Terraced Houses, Journal of Asian Architecture and Building Engineering 6(1), pp.175 182, 2007.5

10) Zainazlan, M. Z., et al. : Hot and humid climate: prospect for thermal comfort in residential building, Desalination 209, pp.261 268, 2007

11) Ministry Finance of Malaysia : Residential Property Stock Report Q1 2009, Property Stock Report, 4, 2009

12) Ahmad S.H. : Reka Bentuk Bandar di Semenanjung Malaysia: Kuala Lumpur dan Bandar Baru di Sekitarnya (英題: Urban design in peninsular malaysia kuala lumpur new city and surrounding areas), Penerbit Universiti Sains Malaysia, pp.142 170, 2005

13) Emmanuel, R., et al : Urban shading - a design option for the tropics? A study in Colombo, Sri Lanka, International Journal of Climatology 27, pp.1995 2004, 2007

14) Chen, Y. and Wong, N.H. : Thermal benefits of city parks, Energy and Buildings 38 pp. 105 120, 2006

15) Wong, N.H. and Jusf, S.K., et al : Environmental study of the impact of greenery in an institutional campus in the tropics, Building and Environment 42, pp.2949 2970, 2007

16) Kakon, A. N. : An Evaluation of Increasing Building Height in Respect of Thermal Climate in a High Density City in South Asia Using Numerical Modeling, Journal of Asian Architecture and Building Engineering 8(2), pp.401 406, 2009.11

17) Michael Bruse, Heribert Fleer : Simulating surface-plant-air interactions inside urban environments with a three dimensional numerical model, Environmental Modelling \& Software 13,pp.373 384, 1998

18) Michael Bruse : ENVI-met 3.0: Updated Model overview, http://www.envi-met.de/documents/papers/overview30.pdf, 2004, 2010.8.23 参照 